\title{
FIXED TRANSPORT COSTS AND INTERNATIONAL TRADE
}

\author{
DIDIER LAUSSEL \\ RAYMOND RIEZMAN
}

CESIFO WORKING PAPER NO. 1764

CATEgORY 7: TRAde Policy

JULY 2006

An electronic version of the paper may be downloaded

- from the SSRN website:

- from the RePEc website:

wWw.SSRN.com

www.RePEc.org

- from the CESifo website: www.CESifo-group.de 


\title{
FIXED TRANSPORT COSTS AND INTERNATIONAL TRADE
}

\author{
Abstract \\ We develop a simple two country model of international trade that assumes that there is a \\ fixed cost of doing international trade. We show that this leads to multiple equilibria that can \\ be Pareto-ranked. We examine the stability properties of these equilibria. \\ JEL Code: F1, F11. \\ Didier Laussel \\ GREQAM, University Aix-Marseille II \\ Aix-en-Provence \\ France \\ laussel@univ-aix.fr \\ Raymond Riezman \\ Department of Economics \\ University of Iowa \\ W210 Pappajohn Business Bldg. \\ Iowa City, IA 52242-1994 \\ USA \\ raymond-riezman@uiowa.edu
}

July 6, 2006 


\section{Introduction}

Explicit treatment of transportation costs has received relatively little attention in the international trade literature. Samuelson (1954), in an analysis of the transfer problem, developed what has become known as the "iceberg" model of transport costs. In the iceberg model, transporting goods costs some proportion of either the goods' value or the physical quantity. The advantage of this approach is that transportation costs simply act as a kind of simple tax for which there is no revenue produced. In international trade models, its like there is a tariff that produces no revenue. In these models the standard trade theorems hold.

The next major theoretical advance in modeling transportation costs was by Falvey (1976). He treats transportation as services that need to be consumed in order for international trade to take place. Falvey explicitly models a transportation sector and shows that in a Heckscher-Ohlin framework the main trade theorems go through and the analysis is modified in straightforward ways. Despite these theoretical developments recent empirical work on transportation costs point in another direction.

Hummels and Skiba (2004) in a paper about whether high or low quality goods are more likely to be exported find that, "...we provide strong evidence against a widely used assumption in the trade literature: that transportation costs are of the 'iceberg' form, proportional to goods prices." In a different context, Hummels and Skiba (2002) argue that economies of scale in transport are important and in part, these economies may derive from large fixed costs of trade. Our purpose here is to explore a model in which there are economies of scale in transport. For simplicity we do this by introducing fixed costs of transportation into a model of international trade and work out the implications.

We develop a simple two country model of international trade that assumes that there is a fixed cost of doing international trade. We show that this leads to multiple equilibria that can be Pareto-ranked. There are high volume of trade, medium volume of trade and no trade (autarky) equilibria. The high trade equilibrium is best and autarky is worst. Then, we examine the stability properties of these equilibria and show that the high trade equilibrium and autarky are stable while the medium volume of trade equilibrium is unstable. We argue that some countries could be in an autarky trap since in the neighborhood of autarky, because of the fixed transportation cost, they would have no incentive to engage in international trade.

The model is developed in section 2, offer curves are derived in section 3, equilibrium solved for in section 4 , a Ricardian example is developed in section 5 , stability and efficiency are discussed in section 6 , and policy conclusions are discussed in section 7 . 


\section{The General Model}

We consider a model in which two goods, labelled 1 and 2, are exchanged between two countries, a home country and a foreign country. All foreign country variables are indicated by asterisks $(*)$. The two goods are produced within each country under perfect competition and with constant returns to scale production functions with the help of $m \geq 1$ internationally immobile factors. The domestic (respectively foreign) prices of the goods 1 and 2 are denoted by $p_{1}$ and $p_{2}$ (respectively $p_{1}^{*}$ and $p_{2}^{*}$ ). Assuming that the production functions exhibit the usual properties (such as the Inada conditions in the two-factor case) the autarkic supply functions (i.e. when no resources are used for transportation) are written as $S_{i}\left(\frac{p_{i}}{p_{j}}\right)$ and $S_{i}^{*}\left(\frac{p_{i}^{*}}{p_{j}^{*}}\right), i, j=1,2, i \neq j$, respectively in the home and foreign countries with $S_{i}^{\prime}>0$ and $S_{i}^{* \prime}>0$.

The role of transportation costs is central in our model. In particular, we are interested in the effect of fixed costs of transportation that may be associated with international trade. These may include the costs of shipping goods from one country to the other or costs of setting up distribution and marketing networks. We focus here on the case when the transportation costs include only fixed (but not sunk) $\operatorname{costs}^{1}$. For simplicity, we suppose that shipping goods from the home (respectively foreign) country to the foreign (respectively home) country requires investing a fraction $\beta$ (respectively $\beta^{*}$ ) of all the domestic (respectively foreign) factor resources whatever the (strictly positive) volume of trade. Together with constant returns to scale (CRS), this assumption allows us to rule out any effect of transportation activities on factor prices. The effect of opening the economy is simply to reduce proportionally by a factor $\beta\left(\beta^{*}\right)$ the stocks of factors available for production activities. Since the CRS assumption rules out size effects, it is clear that at given domestic (respectively foreign) prices the factor prices are the same in free trade as in autarky. It follows that the total domestic (respectively foreign) factor income $Y$ (respectively $Y^{*}$ ) equals its autarkic value, itself equal to the value of the autarkic domestic (respectively foreign) output valued at (the same) domestic (respectively foreign) prices:

$$
\begin{gathered}
Y=p_{1} S_{1}\left(\frac{p_{1}}{p_{2}}\right)+p_{2} S_{2}\left(\frac{p_{2}}{p_{1}}\right) \\
Y^{*}=p_{1}^{*} S_{1}^{*}\left(\frac{p_{1}^{*}}{p_{2}^{*}}\right)+p_{2}^{*} S_{2}^{*}\left(\frac{p_{2}^{*}}{p_{1}^{*}}\right)
\end{gathered}
$$

We assume average cost pricing in transportation activities. These fixed transport costs could be financed in a variety of ways, and while we acknowledge that the method of financing these activities is potentially important, we wish to keep the model as simple as possible in order to focus on the effects of the fixed costs. Accordingly, we assume that when there is international trade the difference between the foreign and the domestic prices of the exported

\footnotetext{
${ }^{1}$ Adding variable costs would not change the results in any significant way.
} 
goods times the volume of exports exactly covers the fixed transportation cost expenditures. This can be thought of as an equilibrium condition: the home (respectively foreign) firms must be indifferent between selling on the home and on the foreign markets.

The equilibrium profits are zero and the total domestic (respectively foreign) income is then equal to the factor income $Y$ (respectively $Y^{*}$ ). Finally the domestic and foreign free trade supply functions may be written respectively as $(1-\beta) S_{i}\left(\frac{p_{i}}{p_{j}}\right)$ and $\left(1-\beta^{*}\right) S_{i}^{*}\left(\frac{p_{i}}{p_{j}}\right), i, j=1,2, \quad i \neq j$, i.e. as fixed fractions of the autarkic supplies.

The consumption demands in the home and foreign countries are derived from the maximization of two thrice continuously differentiable concave utility functions $U\left(C_{1}, C_{2}\right)$ for the home country and $U^{*}\left(C_{1}^{*}, C_{2}^{*}\right)$ for the foreign country subject to the budget constraints which are respectively

$$
p_{1} C_{1}+p_{2} C_{2}=Y
$$

and

$$
p_{1}^{*} C_{1}^{*}+p_{2}^{*} C_{2}^{*}=Y^{*}
$$

We obtain twice-continuously differentiable demand functions:

$$
C_{i}=D_{i}\left(\frac{Y}{p_{i}}, \frac{p_{j}}{p_{i}}\right), i, j=1,2, \quad i \neq j
$$

and

$$
C_{i}^{*}=D_{i}^{*}\left(\frac{Y^{*}}{p_{i}^{*}}, \frac{p_{j}^{*}}{p_{i}^{*}}\right), i, j=1,2, \quad i \neq j
$$

We assume that the first derivatives of these demand functions are strictly positive, i.e. that the two goods are normal. Notice that, given equations (1) and (2) these demands depend only on relative good prices and that they are more conveniently written as

$$
\begin{gathered}
D_{i}\left(\frac{Y}{p_{i}}, \frac{p_{j}}{p_{i}}\right)=d_{i}\left(\frac{p_{j}}{p_{i}}\right) \\
D_{i}^{*}\left(\frac{Y^{*}}{p_{i}^{*}}, \frac{p_{j}^{*}}{p_{i}^{*}}\right)=d_{i}^{*}\left(\frac{p_{j}^{*}}{p_{i}^{*}}\right)
\end{gathered}
$$

As is well known the income and substitution effects have the same sign in the case of exports so that, if $i$ is an exported good, $d_{i}^{\prime}\left(\frac{p_{j}}{p_{i}}\right)>0 \quad\left(d_{i}^{*^{\prime}}\left(\frac{p_{j}}{p_{i}}\right)>0\right)$. The signs of the two effects are opposite in the case of imports so that one cannot say a priori anything on the sign of the above derivatives.

Notice that for given relative prices, these demand functions do not depend on $\beta$ or $\beta^{*}$. This means that transportation costs have no direct effect on demand. 
For convenience, we assume that if trade takes place the home country exports good 1. Hence,

$$
X_{1}(p, \beta)=(1-\beta) S_{1}(p)-d_{1}(p)
$$

and

$$
M_{2}(p, \beta)=d_{2}(p)-(1-\beta) S_{2}(p)
$$

are the export supply and import demand functions of the home country. For the foreign country

$$
X_{2}^{*}\left(p^{*}, \beta^{*}\right)=\left(1-\beta^{*}\right) S_{2}^{*}\left(p^{*}\right)-d_{2}^{*}\left(p^{*}\right)
$$

and

$$
M_{1}^{*}\left(p^{*}, \beta^{*}\right)=d_{1}^{*}\left(p^{*}\right)-\left(1-\beta^{*}\right) S_{1}^{*}\left(p^{*}\right)
$$

are the export supply and import demand functions, respectively.

Average cost pricing in the transportation industries implies that

$$
\left(p_{1}^{*}-p_{1}\right) X_{1}(p, \beta)=\beta\left(p_{1} S_{1}(p)+p_{2} S_{2}(p)\right)
$$

and

$$
\left(p_{2}-p_{2}^{*}\right) X_{2}^{*}\left(p^{*}, \beta^{*}\right)=\beta^{*}\left(p_{1}^{*} S_{1}^{*}\left(p^{*}\right)+p_{2}^{*} S_{2}^{*}\left(p^{*}\right)\right)
$$

From equations (1) and (3) we obtain

$$
p_{1} X_{1}(p, \beta)=p_{2} M_{2}(p, \beta)+\beta\left(p_{1} S_{1}(p)+p_{2} S_{2}(p)\right)
$$

Together with equation (9) we now obtain

$$
v X_{1}(p, \beta)=M_{2}(p, \beta)
$$

where $v=\frac{p_{1}^{*}}{p_{2}}$ denotes the ratio between the c.a.f. prices of the two goods. By a similar argument equations (2), (4) and (10) imply that

$$
v M_{1}^{*}\left(p^{*}, \beta^{*}\right)=X_{2}^{*}\left(p^{*}, \beta^{*}\right)
$$

It is worth noting that these "balance of trade" equilibrium conditions (equations (11) and (12)), contrary to the standard model of international trade without transportation costs, do not simply follow from the domestic and the foreign budget constraints. In order to derive them, we have assumed condition (9) and condition (10). These two conditions already have an equilibrium interpretation: they imply that the domestic (respectively foreign) firms are indifferent between selling on the domestic or the foreign market. If they hold, then international trade is possible and that means that essentially there is now one world market for each good. 


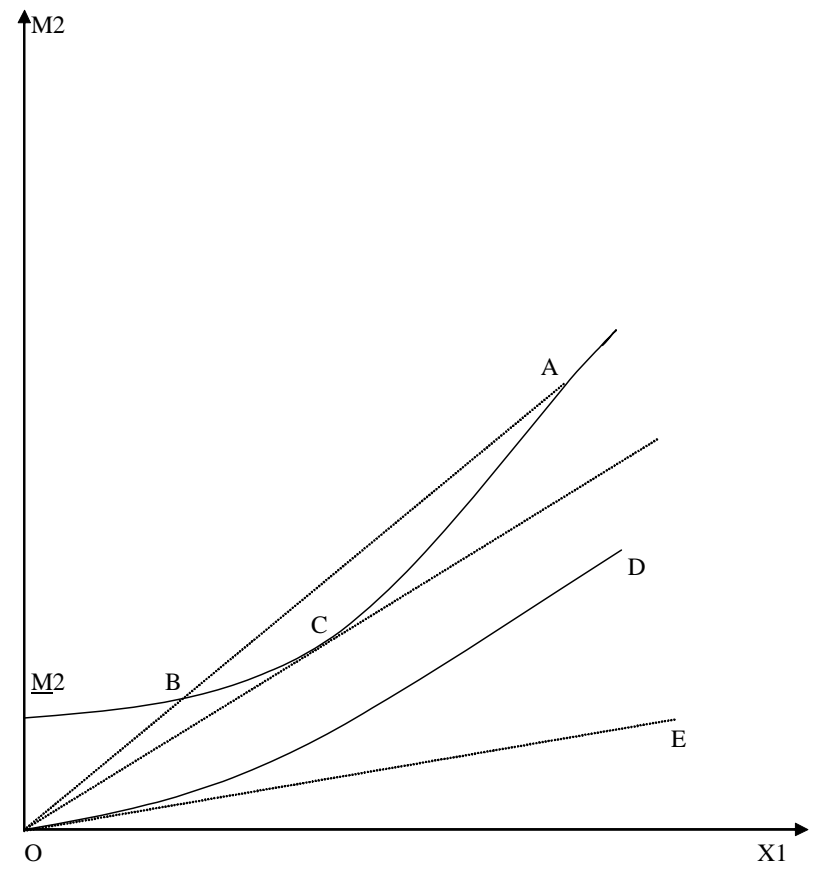

Figure 1:

\section{The Offer Curves}

We are now able to construct the home and foreign "offer curves" that specify the amount of exports a country is willing to supply in exchange for each possible level of imports. Given our previous assumptions if there is international trade then, the home country exports good 1 and exports good 2 while this is the reverse for the foreign country.

In order for international trade to take place each country has to gain enough from trade to cover the fixed transportation costs. For example, the home country is willing to trade if and only if the home domestic relative export price $p$ is not lower than the critical value $\underline{p}(\beta)$ which is unambiguously defined by $X_{1}(\underline{p}(\beta), \beta)=0^{2}$. This critical price is easily proved to be an increasing function of $\beta$. Accordingly, the minimum volume of imports below which the home country is not willing to trade at all is $\underline{M}_{2}(\beta)=M_{2}(\underline{p}(\beta), \beta)$ where $\underline{M}_{2}$ is itself strictly increasing in $\beta$. Since $M_{2}$ is a strictly increasing function of $p$ we may use the Inverse Function Theorem which guarantees the existence of an

${ }^{2}$ given equation $(15)$ it is easy to show that $\underline{p}(\beta) \geq p^{A}$. 
inverse function $\rho \equiv M_{2}^{-1}$. The offer curve of the home country is now simply defined as

$$
X_{1}=f\left(M_{2}, \beta\right)=\max \left\{0, X_{1}\left(\rho\left(M_{2}, \beta\right), \beta\right)\right\}
$$

Obviously, $f\left(M_{2}, \beta\right)=0$ for all $M_{2} \leq \underline{M}_{2}(\beta)$. Moreover $\frac{\partial f\left(M_{2}, \beta\right)}{\partial \beta}<0$.To see how the offer curve is affected by fixed transportation costs consider Figure 1. The usual domestic offer curve with no fixed transportation costs $(\beta=0)$ is $O D$. It is convex since to a given domestic price ratio $p$ must correspond under the usual assumptions to one and only one couple $\left(X_{1}, M_{2}\right)$. We assume that it is strictly convex ${ }^{3}$. The slope of the tangent $O E$ to $O D$ at the origin is equal to the autarkic equilibrium price ratio $p^{A}$.

Now consider the home country offer curve when there are fixed transport costs. The home country offer curve corresponding to some $\beta>0$ is $O \underline{M}_{2} A$. At any point $A$ on the home country offer curve we deduce from equation (11) that the value of the international relative price $v$ equals the slope of $O A$. For sufficiently low values of $\beta$ it must be convex for all $M_{2}>\underline{M}_{2}(\beta)$ as pictured above. A necessary condition for the home country being willing to trade is obviously that the international relative price $v$ of good 1 be larger than a value $\underline{v}(\beta)$ equal to the slope of $O C$ which is itself strictly larger than the autarkic equilibrium price ratio $p^{A}$. Thus, with fixed transportation costs the domestic country requires more gains from trade (a higher relative price for good 1) before it is willing to engage in international trade. Of course $\underline{v}(\beta)$ tends toward $p^{A}$ as $\beta$ tends toward 0 . Notice that for any value of $v$ larger than $\underline{v}(\beta)$ there correspond two points on the home offer curve and hence two possible trade vectors and two possible values of the domestic relative price $p$.

The foreign offer curve is affected in the same way. The foreign country is willing to trade if and only if the foreign domestic relative price of imports $p^{*}$ is not larger than a critical value $\bar{p}^{*}\left(\beta^{*}\right)$ unambiguously defined by $X_{2}^{*}\left(\bar{p}^{*}\left(\beta^{*}\right), \beta^{*}\right)=0$. Accordingly, the minimum volume of imports below which the foreign country is not willing to trade is $\underline{M}_{1}^{*}\left(\beta^{*}\right)=M_{1}^{*}\left(\bar{p}^{*}\left(\beta^{*}\right), \beta^{*}\right)$ and is strictly increasing in $\beta^{*}$. $M_{1}^{*}$ being a strictly decreasing function of $p^{*}$ we may use the Inverse Function Theorem which guarantees the existence of $M_{1}^{*-1} \equiv \sigma$. The offer curve of the foreign country is then simply

$$
\left.X_{2}^{*}=f^{*}\left(M_{1}^{*}, \beta^{*}\right)=\max \left\{0, X_{2}^{*}\left(\sigma\left(M_{1}^{*}, \beta^{*}\right), \beta^{*}\right)\right)\right\}
$$

Notice that $f^{*}\left(M_{1}^{*}, \beta^{*}\right)=0$ for all $M_{1}^{*} \leq \underline{M}_{1}^{*}\left(\beta^{*}\right)$ and that $\frac{\partial f^{*}\left(M_{1}^{*}, \beta^{*}\right)}{\partial \beta^{*}}<0$.

Figure 2 shows foreign country offer curves for $\beta^{*}=0$ and $\beta^{*}>0$. At any point $A$ on this curve it follows from equation (12) that the corresponding international price ratio $v$ equals the slope of $O A$. By the same argument used above for establishing the convexity of the home offer curve, the foreign offer

\footnotetext{
${ }^{3}$ This amounts to ruling out flat parts of the usual offer curves as occur in the Ricardian case. This assumption ensures that for low transport costs and a volume of imports above a given minimum the home offer curve is convex. However as shown in Section 5 for the Ricardian case, this assumption is too strong: in this case indeed the home offer curve is unambiguously convex for any value of $\beta$ provided that $M_{2}>\underline{M}_{2}(\beta)$.
} 


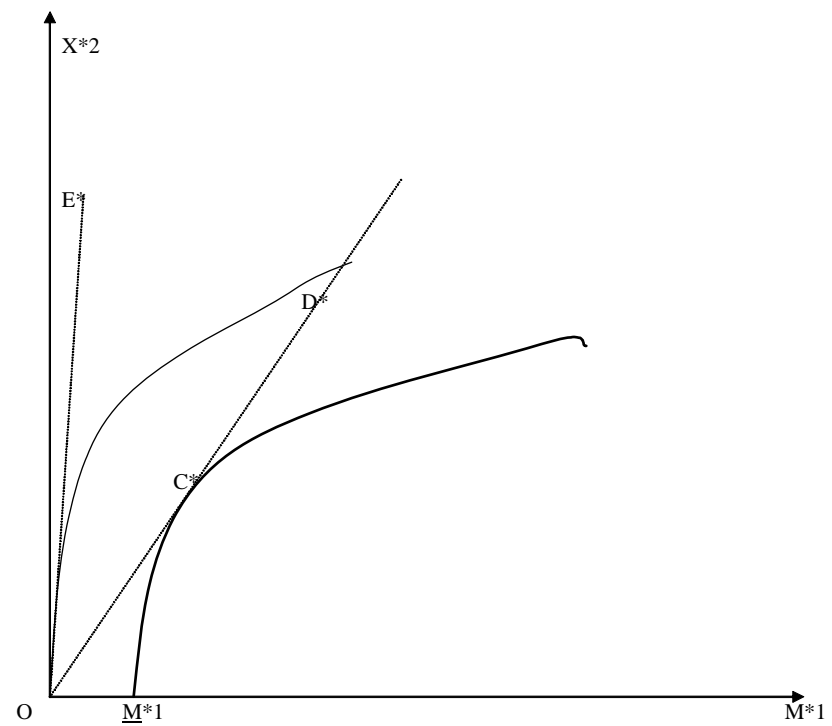

Figure 2: 
curve is concave for sufficiently low values of $\beta^{*}$ and for values of $M_{1}^{*}$ larger than $\underline{M}_{1}^{*}\left(\beta^{*}\right)$. The foreign country is willing to trade if and only if the international price ratio $v$ is lower than the critical value $\bar{v}\left(\beta^{*}\right)$ corresponding to the slope of the tangent $O C^{*}$ to the offer curve from the origin. Of course $\bar{v}\left(\beta^{*}\right)$ is lower than the foreign autarkic price ratio $p^{A *}$ given by the slope of $\mathrm{OE}^{*}$.

\section{The Equilibria}

The autarkic equilibrium (relative) prices $p^{A}$ and $p^{* A}$ (notice that $p=\frac{p_{1}}{p_{2}}$ and $\left.p^{*}=\frac{p_{1}^{*}}{p_{2}^{*}}\right)$ satisfy the market-clearing conditions (from Walras Law equilibrium on the first market entails equilibrium on the second market) :

$$
\begin{aligned}
S_{1}\left(p^{A}\right) & =d_{1}\left(\frac{1}{p^{A}}\right) \\
S_{1}^{*}\left(p^{A *}\right) & =d_{1}\left(\frac{1}{p^{A *}}\right)
\end{aligned}
$$

We assume without loss of generality that $p^{A}<p^{A *}$, i.e. that the home country has a comparative advantage in good 1.

Whenever the fixed transportation costs are both strictly positive (i.e. whenever $\beta>0$ and/or $\beta^{*}>0$ ) autarky is an equilibrium of our model. When the volume of trade is arbitrarily low no firm expects to be able to cover the fixed cost expenditures which it would have to make in order to enter the transportation industry. Put another way, at autarky, the prices of transportation services per unit of good shipped are so large as to discourage any trade ${ }^{4}$. This looks like a "low level equilibrium trap": there is no trade because at the margin transportation costs are very large but the transportation costs are large because there is no trade. However, it remains to show that there may also exist equilibria with positive volumes of trade.

An international (i.e. with positive trade) equilibrium of this model is formally a triple of relative prices $\left(p, p^{*}, v\right)$ such that (i) the two goods markets clear and (ii) the two transportation industries break even. As usual, owing to Walras Law, one of these conditions is redundant so that one is left with three equations in three unknowns. Interestingly enough the two goods market clearing equations are

$$
(1-\beta) S_{1}(\widehat{p})+\left(1-\beta^{*}\right) S_{1}^{*}\left(\widehat{p}^{*}\right)=d_{1}\left(\frac{1}{\widehat{p}}\right)+d_{1}^{*}\left(\frac{1}{\widehat{p}^{*}}\right)
$$

and

$$
(1-\beta) S_{2}\left(\frac{1}{\widehat{p}}\right)+\left(1-\beta^{*}\right) S_{2}^{*}\left(\frac{1}{\widehat{p}^{*}}\right)=d_{2}(\widehat{p})+d_{2}^{*}\left(\widehat{p}^{*}\right)
$$

\footnotetext{
${ }^{4}$ They indeed tend toward infinity.
} 
These equations determine the domestic relative prices in the home and foreign countries and thereby all the relevant quantities (output, consumption, import and export levels ) independently of the budget balance conditions for the transportation industries. Then either condition (11) or condition (12) determines the international price ratio $v$ so as to satisfy budget balance in the transportation industry.

To see how the model works it helps to first consider the classical case without transportation costs $\left(\beta=\beta^{*}=0\right)$. Here, at free trade, the two relative prices, home and foreign, must coincide in equilibrium $\left(p=p^{*}=v\right)$ and conditions (11) and (12) are automatically satisfied. Moreover, from Walras Law, the second market clears if the first one does (and reciprocally) so that we are left with only one equilibrium condition, say equation (16), which may be written as $E_{1}(v)=d_{1}\left(\frac{1}{v}\right)+d_{1}^{*}\left(\frac{1}{v}\right)-S_{1}(v)-S_{1}^{*}(v)=0$. Under standard assumptions the excess demand for good $1\left(E_{1}\right)$ is a continuous function of $v$, is positive when $v=0$, and tends toward a strictly negative value when $v$ tends toward infinity. This ensures the existence of at least one equilibrium, i.e. of a value $\widehat{v}$ such that $E_{1}(\widehat{v})=0$. As is well-known, this equilibrium is unique whenever the condition below is satisfied.

Condition 1 (Marshall-Lerner) $\varepsilon(v)+\varepsilon^{*}(v)>1$

Where $\varepsilon(v)$ and $\varepsilon^{*}(v)$ are respectively the home and foreign price-elasticities of imports. Recalling that home imports of good 2 are $M_{2}=C_{2}-S_{2}$ and foreign imports of good 1 are $M_{1}^{*}=C_{1}^{*}-S_{1}^{*}$, then $\varepsilon(v)=\frac{v M_{2}^{\prime}(v)}{M_{2}(v)}$ and $\varepsilon^{*}(v)=-\frac{v M_{1}^{*^{\prime}}(v)}{M_{1}^{*}(v)}$.

We next turn to determining equilibrium. Equilibrium occurs when the two offer curves intersect since that is where import demands are equal to export supplies. In the case without transportation costs (dotted curves in Figure 3), the Marshall-Lerner Condition ensures that the offer curves cut only twice, at $\mathrm{O}$ (autarky) and at $\mathrm{E}$ (free trade equilibrium.) However, only $\mathrm{E}$ corresponds to an equilibrium since at $\mathrm{O}$ the relative prices $p^{A}$ and $p^{A *}$ differ, giving rise to the possibility of costless and profitable trade.

When there exist small but strictly positive transportation costs a simple continuity argument shows that there now exist two international equilibria with positive amounts of trade, a "high" equilibrium at $\mathrm{H}$, near $\mathrm{E}$, and an "intermediate" equilibrium at $\mathrm{I}$, near $\mathrm{O}$ with an international equilibrium price ratio respectively equal to the slopes of $\mathrm{OH}$ and of OI. Moreover as shown above autarky now becomes an equilibrium with equilibrium home and foreign autarkic relative prices equal to the slopes of $\mathrm{OE}$ and $\mathrm{OE}^{*}$.

Proposition 1 For small enough values of $\beta$ and $\beta^{*}$, such that at least $\beta$ or $\beta^{*}>0$, there exist three equilibria which are ranked by increasing volumes of trade: autarky, an "intermediate trade" equilibrium and a "high trade" equilibrium.

To illustrate how the equilibrium works we consider an example of a Ricardian economy. 


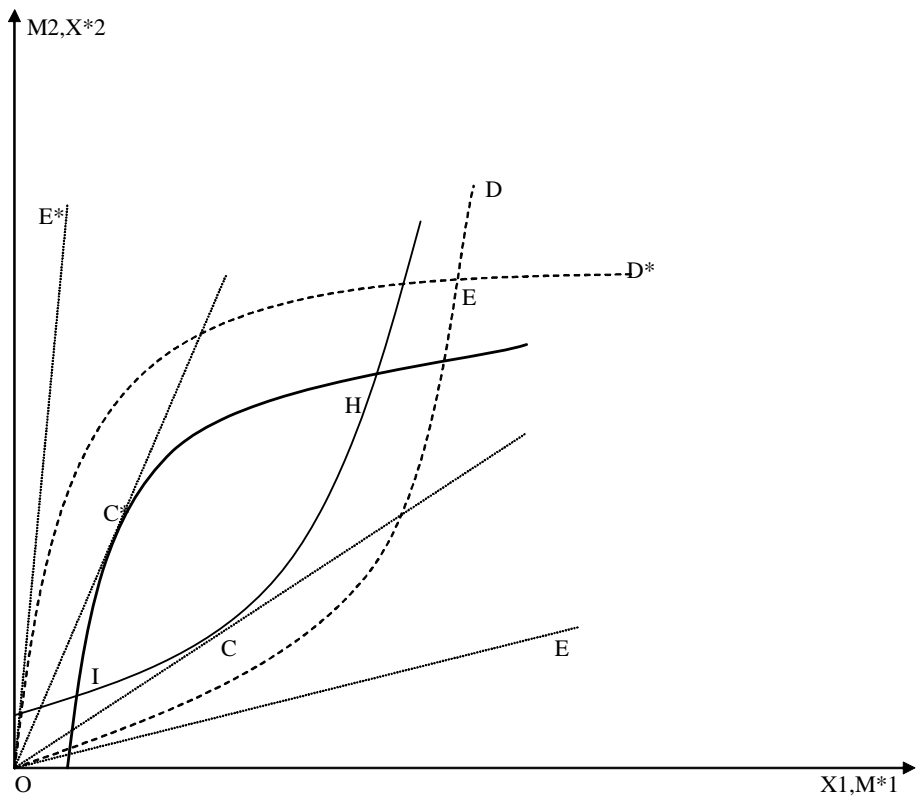

Figure 3: 


\section{The Ricardian case}

Here labor is the only factor both in production and transportation activities. The unit labor requirement in the production of good $i$ in the home country is $a_{i}$. All foreign country variables are indicated by asterisks $\left(^{*}\right)$. Without loss of generality we assume as in the previous Sections that the home country has a comparative advantage in the production of good 1, or, equivalently, that the foreign country has a comparative advantage in the production of good 2, i.e.

Assumption 1: $\frac{a_{1}}{a_{2}}<\frac{a_{1}^{*}}{a_{2}^{*}}$.

Straightforwardly here if $p=\frac{a_{1}}{a_{2}}$

$$
\begin{aligned}
S_{i}(p) & \in\left[0, \frac{L}{a_{1}}\right], i=1,2 \\
Y & =\frac{L}{a_{1}} \frac{a_{1}}{a_{2}}
\end{aligned}
$$

and

$$
\begin{aligned}
& M_{2} \in\left[0, d_{2}\left(\frac{a_{1}}{a_{2}}\right)\right] \\
& X_{1}=M_{2} \frac{a_{2}}{a_{1}}-\frac{\beta L}{a_{1}}
\end{aligned}
$$

If $p \geq \frac{a_{1}}{a_{2}}$

$$
\begin{aligned}
S_{1}(p) & =\frac{L}{a_{1}} \\
S_{2}(p) & =0 \\
Y & =\frac{L}{a_{1}} p
\end{aligned}
$$

and

$$
\begin{aligned}
& M_{2}=d_{2}(p) \\
& X_{1}=p d_{2}(p)-\frac{\beta L}{a_{1}}
\end{aligned}
$$

It is then easy to build the home offer curve as

$$
\begin{aligned}
& X_{1}=0 \text { when } M_{2} \in\left[0, \frac{\beta L}{a_{2}}\right] \\
& X_{1}=M_{2} \frac{a_{2}}{a_{1}}-\frac{\beta L}{a_{1}} \text { when } M_{2} \in\left[\frac{\beta L}{a_{2}}, d_{2}\left(\frac{a_{1}}{a_{2}}\right)\right] \\
& X_{1}=\frac{M_{2}}{d_{2}^{-1}\left(M_{2}\right)}-\frac{\beta L}{a_{1}} \text { when } M_{2} \geq d_{2}\left(\frac{a_{1}}{a_{2}}\right)
\end{aligned}
$$




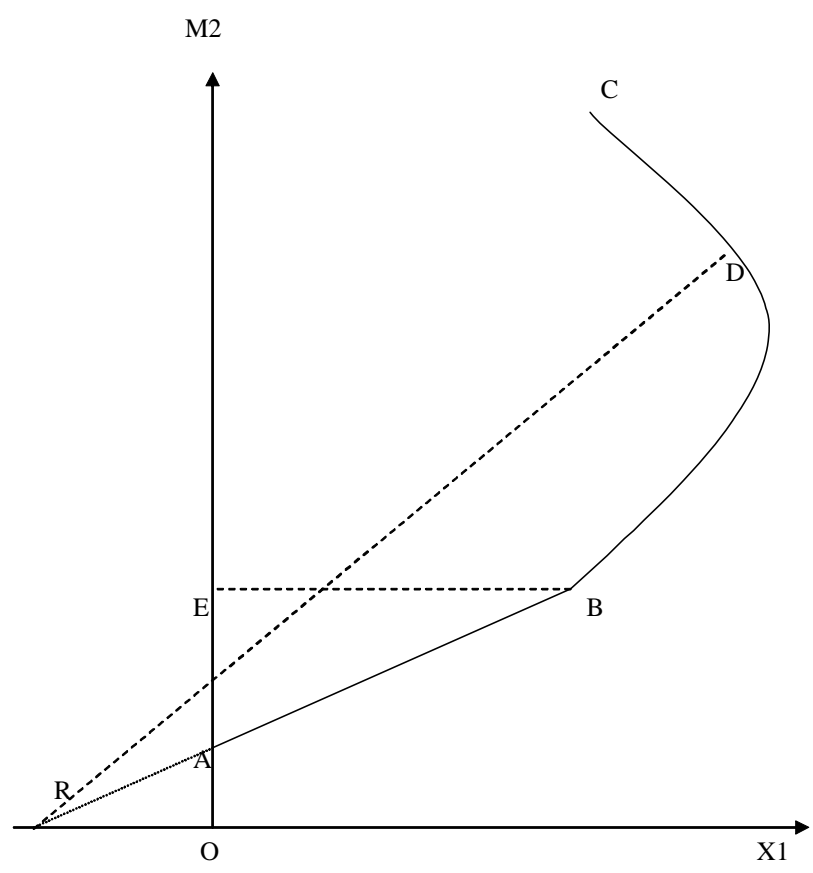

Figure 4:

Figure 4 below illustrates the determination of country $A$ 's offer curve OABC. Note that $\mathrm{OA}=\frac{F}{a_{2}}, \mathrm{OR}=-\frac{F}{a_{1}}$ and $\mathrm{OE}=g_{A 2}\left(\frac{a_{1}}{a_{2}}\right)$. The slope of $\mathrm{OB}$ equals $\frac{a_{1}}{a_{2}}$. The coordinates of point D for instance give the amounts of exports of good 1 and imports of good 2 which country $A$ wants to trade when the domestic price ratio $\frac{p_{1}}{p_{2}}$ equals the slope of $\mathrm{RD}$. The specificity of the Ricardian case is the existence of a flat part of the offer curves (AB in Figure 2).

Using similar arguments the foreign offer curve is then derived as:

$$
\begin{aligned}
& X_{2}^{*}=0 \text { when } M_{1}^{*} \in\left[0, \frac{\beta^{*} L^{*}}{a_{1}^{*}}\right] \\
& X_{2}^{*}=M_{1}^{*} \frac{a_{1}^{*}}{a_{2}^{*}}-\frac{\beta^{*} L^{*}}{a_{2}^{*}} \text { when } M_{1}^{*} \in\left[\frac{\beta^{*} L^{*}}{a_{1}^{*}}, d_{1}^{*}\left(\frac{a_{2}^{*}}{a_{1}^{*}}\right)\right] \\
& X_{2}^{*}=\frac{M_{1}^{*}}{d_{1}^{*-1}\left(M_{1}^{*}\right)}-\frac{\beta^{*} L^{*}}{a_{2}^{*}} \text { when } M_{1}^{*} \geq d_{1}^{*}\left(\frac{a_{2}^{*}}{a_{1}^{*}}\right)
\end{aligned}
$$

If and only if the values of $\beta$ and $\beta^{*}$ are low enough so as to satisfy the 
inequalities below

$$
\frac{\beta^{*} L^{*} a_{2}+\beta L a_{2}^{*}}{a_{1}^{*} a_{2}-a_{1} a_{2}^{*}} \leq d_{1}^{*}\left(\frac{a_{2}^{*}}{a_{1}^{*}}\right)
$$

and

$$
\frac{\beta^{*} L^{*} a_{1}+\beta L a_{1}^{*}}{a_{1}^{*} a_{2}-a_{1} a_{2}^{*}} \leq d_{2}\left(\frac{a_{1}}{a_{2}}\right)
$$

there exists an intermediate equilibrium where the flat parts of the two offer curves intersect: at this equilibrium the two countries produce the two goods ${ }^{5}$ and the relative internal equilibrium prices equal their respective autarkic values, i.e. $p=\frac{a_{1}}{a_{2}}$ and $p^{*}=\frac{a_{2}^{*}}{a_{1}^{*}}$. At this equilibrium $X_{1}=M_{1}^{*}=\frac{\beta^{*} L^{*} a_{2}+\beta L a_{2}^{*}}{a_{1}^{*} a_{2}-a_{1} a_{2}^{*}}$ and $X_{2}^{*}=M_{2}=\frac{\beta^{*} L^{*} a_{1}+\beta L a_{1}^{*}}{a_{1}^{*} a_{2}-a_{1} a_{2}^{*}}$. The welfare at this intermediate equilibrium is the same in both countries as at the autarkic equilibrium. This follows simply from the fact that the relative internal prices and hence the consumption levels are identical. It is indeed easy to see that the amounts of labor which are saved in the two countries by having each of them produce more of the good in which it has a comparative advantage and less of the other are exactly equal to the quantities of labor required in order to ship the goods between countries, namely $M_{1}^{*}\left(a_{1}^{*}-a_{1}\right)+M_{2}\left(a_{2}-a_{2}^{*}\right)=\beta L+\beta^{*} L^{*}$. From the general Proposition 1 for small enough values of $\beta$ and $\beta^{*}$ there also exists a high equilibrium . At this equilibrium at least country is fully specialized. This is pictured in Figure 5 below for the case where both countries are fully specialized at $\mathrm{H}$.

We next turn to consideration of the properties of these three equilibria.

\section{Stability and Efficiency}

\subsection{Stability}

In this section we confine ourselves to the case of positive fixed transport costs of trade $\left(\beta>0\right.$ and $\left.\beta^{*}>0\right)$. We begin by investigating the (local) Walrasian stability of the three equilibria. The essential idea of Walrasian stability is that an equilibrium is stable if, when price is above the equilibrium price, then supply exceeds demand. If the price is below the equilibrium price, then demand exceeds supply. We are willing to define here stability along these lines. An international equilibrium has been defined above as a triple of relative prices. In order to analyze a simple tâtonnement process in a neighborhood of an international equilibrium we require that conditions (11) and (12) be satisfied everywhere, i.e. there is average cost pricing of transportation services even out of equilibrium. Under this assumption there are, in a neighborhood of an international equilibrium like $\mathrm{H}$ or I, two one to one correspondences, defined by (11) and (12), between the international price ratio $v$ and, respectively, the home and foreign domestic price ratios $p$ and $p^{*}$. It follows that the value of

\footnotetext{
${ }^{5}$ whereas efficiency requires that one country at least be fully specialized.
} 


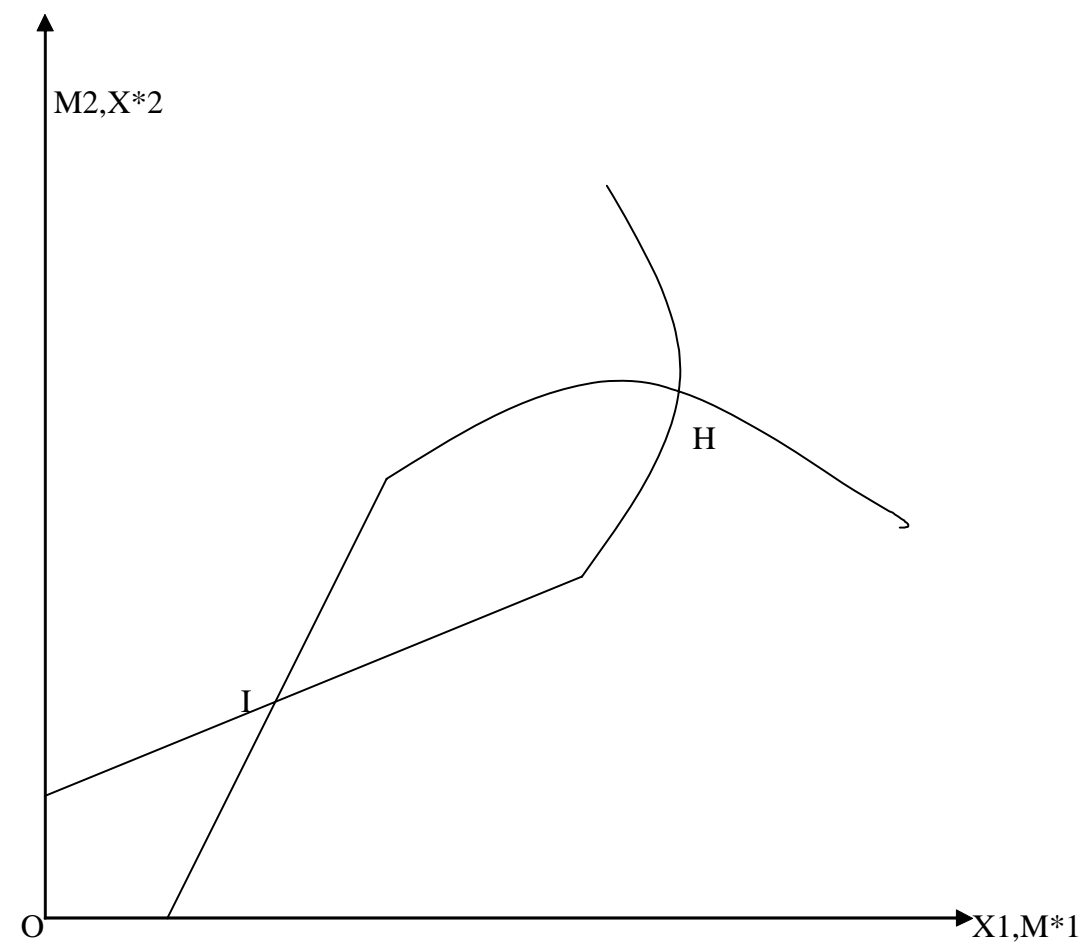

Figure 5: 
$v$ completely determines the initial conditions of the tâtonnement process in a neighborhood of an international equilibrium

Definition: Equilibrium price $v^{0}$ is a locally stable international equilibrium price if the following two conditions hold:

a.) $v \geq v^{0} \Rightarrow X_{1}(v) \geq M_{1}^{*}(v)$ and $M_{2}(v) \geq X_{2}^{*}(v)$

b.) $v \leq v^{0} \Rightarrow X_{1}(v) \leq M_{1}^{*}(v)$ and $M_{2}(v) \leq X_{2}^{*}(v)$.

Using this definition we determine which of the two international equilibria equilibria we have is stable. The three equilibria are illustrated in Figure 6. We have the "high" equilibrium at $\mathrm{H}$, the "intermediate" equilibrium at I and autarky at 0 . First, consider the high equilibrium. Suppose that the international price $v$ is less than the equilibrium price $v^{0}$. At that price the home country will trade at point $\mathrm{B}$ and the foreign country at point $\mathrm{C}$. It is clear from Figure 6 this means that the foreign demand for imports of good one exceeds the home supply of exports of good one and in the market for good two, foreign export supply exceed home import demand. That is, when $v \leq v^{0} \Rightarrow X_{1}(v) \leq M_{1}^{*}(v)$ and $M_{2}(v) \leq X_{2}^{*}(v)$, hence condition $\mathrm{b}$ is satisfied. If we consider prices above equilibrium, it is also clear that the reasoning above is simply reversed and condition a is satisfied. Therefore, $H$ is a stable equilibrium.

Next consider equilibrium point I. If we consider a price below equilibrium then the home country would trade at B in Figure 7 and the foreign country would trade at $\mathrm{A}$. That means that when the price is below the equilibrium the foreign demand for imports of good one is less than the home supply of exports of good one and in the market for good two, foreign export supply falls short of home import demand. Thus, if $v \leq v^{0} \Rightarrow X_{1}(v) \geq M_{1}^{*}(v)$ and $M_{2}(v) \geq X_{2}^{*}(v)$ and condition $\mathrm{b}$ is violated. The reader can easily verify that condition a also fails and therefore, the equilibrium at I is unstable.

Finally, and perhaps, most importantly, consider autarky. In the case of autarky we have to consider the relative prices in each country. Stability of autarky requires that in the home country for a value of $p$ larger (respectively lower) than $p^{A}$ there is an excess supply of (respectively excess demand for) good 1 and an excess demand for (respectively excess supply of) good 2 on the home markets and symmetrically in the foreign country. This turns out to be true in a neighborhood of autarkic prices since $p^{A}<\underline{p}(\beta)$ and $p^{* A}>\bar{p}^{*}\left(\beta^{*}\right)$. When the domestic price ratios $p$ and $p^{*}$ do not differ significantly from their autarkic equilibrium values the two countries do not want to trade. Due to the fixed transport costs the excess of production over domestic demand of some good does not translate into some positive export supply.

We summarize these results in a proposition.

Proposition 2 (Stability) The high trade equilibrium and autarky are stable equilibria. The low trade equilibrium is unstable. 


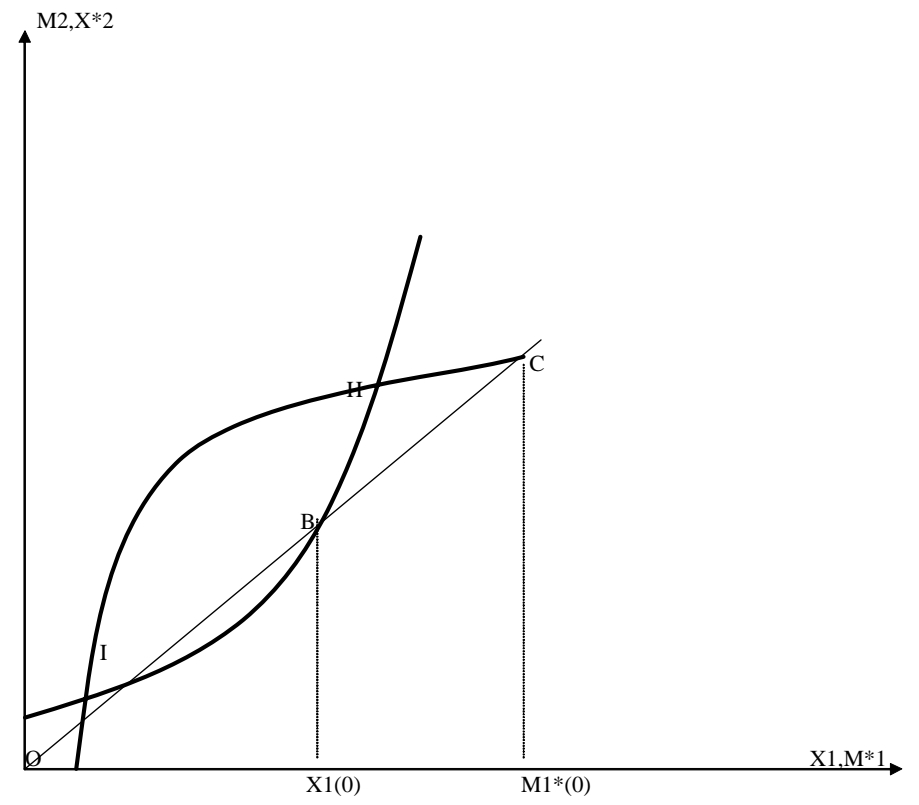

Figure 6: 


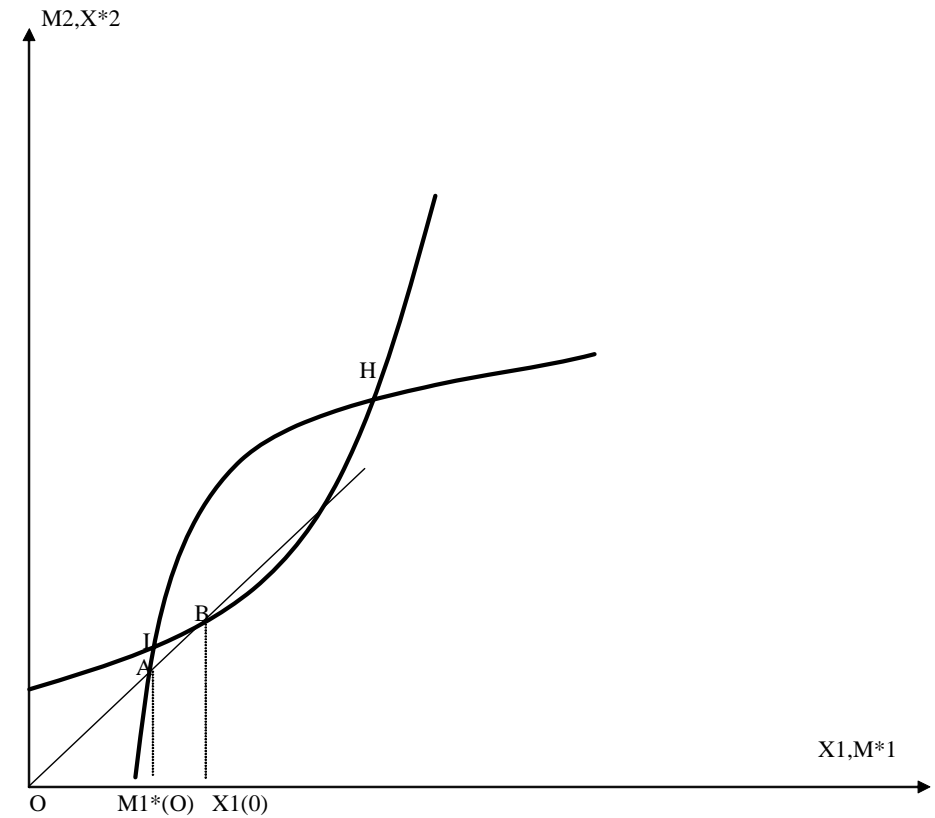

Figure 7: 


\subsection{Efficiency}

We next consider efficiency. The central question we ask is whether the three equilibria can be ranked? We are able to show that in fact, all three equilibria can be Pareto-ranked.

Proposition 3 (Efficiency) With fixed costs of transportation the three equilibria can be Pareto-ranked. The high trade equilibrium Pareto-dominates the intermediate trade equilibrium which in turn, Pareto-dominates the autarkic equilibrium.

Proof. First, consider the home offer curve. It follows from convexity assumptions made earlier that, moving from the left to the right on the home offer curve means $M_{2}$ is increasing as is $p$. So, $M_{2}$ is increasing in $p$. By the same argument $M_{1}^{*}$ is decreasing in $p^{*}$ moving from the left to the right on the foreign offer curve. It follows then, that at the high equilibrium point $H, \quad p$ is higher and $p^{*}$ is lower than at the intermediate equilibrium point I. This means that the wedge between the internal home and foreign relative prices is lower at $H$ than at I. This reasoning also shows that the wedge is lower at I than it is at $O$. The second step is now to show that the home welfare $W(p)=U\left(C_{1}(p), C_{2}(p)\right)$ is increasing in $p$ while the foreign welfare $W^{*}\left(p^{*}\right)=U^{*}\left(C_{1}^{*}\left(p^{*}\right), C_{2}^{*}\left(p^{*}\right)\right)$ is decreasing in $p^{*}$. We obtain

$$
W^{\prime}(p)=U_{1}^{\prime}\left(C_{1}(p), C_{2}(p)\right) C_{1}^{\prime}(p)+U_{2}^{\prime}\left(C_{1}(p), C_{2}(p)\right) C_{2}^{\prime}(p)
$$

and then, using the first-order conditions of the home consumer's problem

$$
W^{\prime}(p)=U_{2}^{\prime}\left(C_{1}(p), C_{2}(p)\right)\left[p C_{1}^{\prime}(p)+C_{2}^{\prime}(p)\right]
$$

From equations (1) and (3)

$$
p C_{1}^{\prime}(p)+C_{2}^{\prime}(p)+C_{1}(p)=p S_{1}^{\prime}(p)+S_{2}^{\prime}(p)+S_{1}(p)
$$

Since at equilibrium the home national income is maximized $p S_{1}^{\prime}(p)+S_{2}^{\prime}(p)=$ 0 and we can safely conclude that

$$
W^{\prime}(p)=U_{2}^{\prime}\left(C_{1}(p), C_{2}(p)\right)\left[S_{1}(p)-C_{1}(p)\right]>0
$$

By the same argument

$$
W^{*^{\prime}}\left(p^{*}\right)=-\frac{U_{1}^{*^{\prime}}\left(C_{1}^{*}(p), C_{2}^{*}(p)\right)}{p^{* 2}}\left[S_{2}^{*}\left(p^{*}\right)-C_{2}^{*}\left(p^{*}\right)\right]<0
$$

Remark: Though the "high trade equilibrium", when it exists, Paretodominates both the intermediate and the autarkic equilibrium it is not Paretoefficient. Efficiency would indeed require that prices equal marginal costs. Specifically, since the marginal transport costs are zero in this model there should be no difference between home and foreign prices. This is not the case 
here owing to average cost pricing in the transportation industries: import prices are above marginal costs in both countries and the levels of consumption of imported (respectively exported) goods are accordingly below (respectively above) their optimal levels.

\section{Concluding remarks and extensions}

The basic message of this paper is clear. While there may exist some scope for mutually profitable North-South (interindustry) trade based on comparative advantage the world may well be trapped in some low level equilibrium (here the autarkic one) where, due to the existence of fixed transportation costs, low trade volumes lead to large unit transport prices which themselves induce in turn low trade volumes. The dimension of this "trap" can be informally measured by the distance between this (stable) low level equilibrium and the (unstable) intermediate equilibrium, a distance which is increasing in the fixed transportation costs. One could think that getting out of this trap may require some kind of "big push", for instance some public investments in transport infrastructures: by doing so one could expect the emergence of a "high trade" equilibrium. Moreover, if these investments be financed by lump-sum taxation, an additional source of inefficiency, the divergence between the home and foreign relative prices, could be eliminated. Notice, however, that such a move would require some coordination between the governments of the two countries.

\section{References}

\section{References}

[1] Hummels, David and Alexandre Skiba, (2002), "A Virtuous Circle? Regional Tariff Liberalization and Scale Economies in Transport," mimeo.

[2] Hummels, David and Alexandre Skiba, (2004) "Shipping the Good Apples Out? An Empirical Confirmation of the Alchain-Allen Conjecture," forthcoming Journal of Political Economy.

[3] Falvey, Rodney, (1976), "Transport Costs in the Pure Theory of International Trade," The Economic Journal, 86, 536-550.

[4] Samuelson, Paul, (1954), "The Transfer Problem and Transport Costs, II: Analysis of Effects of Trade Impediments," The Economic Journal, 64, 264289. 


\title{
CESifo Working Paper Series
}

\author{
(for full list see www.cesifo-group.de)
}

1701 Christian Groth, Karl-Josef Koch and Thomas M. Steger, Rethinking the Concept of Long-Run Economic Growth, April 2006

1702 Dirk Schindler and Guttorm Schjelderup, Company Tax Reform in Europe and its Effect on Collusive Behavior, April 2006

1703 Françoise Forges and Enrico Minelli, Afriat's Theorem for General Budget Sets, April 2006

1704 M. Hashem Pesaran, Ron P. Smith, Takashi Yamagata and Liudmyla Hvozdyk, Pairwise Tests of Purchasing Power Parity Using Aggregate and Disaggregate Price Measures, April 2006

1705 Piero Gottardi and Felix Kubler, Social Security and Risk Sharing, April 2006

1706 Giacomo Corneo and Christina M. Fong, What's the Monetary Value of Distributive Justice?, April 2006

1707 Andreas Knabe, Ronnie Schoeb and Joachim Weimann, Marginal Employment Subsidization: A New Concept and a Reappraisal, April 2006

1708 Hans-Werner Sinn, The Pathological Export Boom and the Bazaar Effect - How to Solve the German Puzzle, April 2006

1709 Helge Berger and Stephan Danninger, The Employment Effects of Labor and Product Markets Deregulation and their Implications for Structural Reform, May 2006

1710 Michael Ehrmann and Marcel Fratzscher, Global Financial Transmission of Monetary Policy Shocks, May 2006

1711 Carsten Eckel and Hartmut Egger, Wage Bargaining and Multinational Firms in General Equilibrium, May 2006

1712 Mathias Hoffmann, Proprietary Income, Entrepreneurial Risk, and the Predictability of U.S. Stock Returns, May 2006

1713 Marc-Andreas Muendler and Sascha O. Becker, Margins of Multinational Labor Substitution, May 2006

1714 Surajeet Chakravarty and W. Bentley MacLeod, Construction Contracts (or "How to Get the Right Building at the Right Price?”), May 2006

1715 David Encaoua and Yassine Lefouili, Choosing Intellectual Protection: Imitation, Patent Strength and Licensing, May 2006 
1716 Chris van Klaveren, Bernard van Praag and Henriette Maassen van den Brink, Empirical Estimation Results of a Collective Household Time Allocation Model, May 2006

1717 Paul De Grauwe and Agnieszka Markiewicz, Learning to Forecast the Exchange Rate: Two Competing Approaches, May 2006

1718 Sijbren Cnossen, Tobacco Taxation in the European Union, May 2006

1719 Marcel Gérard and Fernando Ruiz, Interjurisdictional Competition for Higher Education and Firms, May 2006

1720 Ronald McKinnon and Gunther Schnabl, China’s Exchange Rate and International Adjustment in Wages, Prices, and Interest Rates: Japan Déjà Vu?, May 2006

1721 Paolo M. Panteghini, The Capital Structure of Multinational Companies under Tax Competition, May 2006

1722 Johannes Becker, Clemens Fuest and Thomas Hemmelgarn, Corporate Tax Reform and Foreign Direct Investment in Germany - Evidence from Firm-Level Data, May 2006

1723 Christian Kleiber, Martin Sexauer and Klaus Waelde, Bequests, Taxation and the Distribution of Wealth in a General Equilibrium Model, May 2006

1724 Axel Dreher and Jan-Egbert Sturm, Do IMF and World Bank Influence Voting in the UN General Assembly?, May 2006

1725 Swapan K. Bhattacharya and Biswa N. Bhattacharyay, Prospects of Regional Cooperation in Trade, Investment and Finance in Asia: An Empirical Analysis on BIMSTEC Countries and Japan, May 2006

1726 Philippe Choné and Laurent Linnemer, Assessing Horizontal Mergers under Uncertain Efficiency Gains, May 2006

1727 Daniel Houser and Thomas Stratmann, Selling Favors in the Lab: Experiments on Campaign Finance Reform, May 2006

1728 E. Maarten Bosker, Steven Brakman, Harry Garretsen and Marc Schramm, A Century of Shocks: The Evolution of the German City Size Distribution 1925 - 1999, May 2006

1729 Clive Bell and Hans Gersbach, Growth and Enduring Epidemic Diseases, May 2006

1730 W. Bentley MacLeod, Reputations, Relationships and the Enforcement of Incomplete Contracts, May 2006

1731 Jan K. Brueckner and Ricardo Flores-Fillol, Airline Schedule Competition: ProductQuality Choice in a Duopoly Model, May 2006

1732 Kerstin Bernoth and Guntram B. Wolff, Fool the Markets? Creative Accounting, Fiscal Transparency and Sovereign Risk Premia, May 2006 
1733 Emmanuelle Auriol and Pierre M. Picard, Government Outsourcing: Public Contracting with Private Monopoly, May 2006

1734 Guglielmo Maria Caporale and Luis A. Gil-Alana, Modelling Structural Breaks in the US, UK and Japanese Unemployment Rates, May 2006

1735 Emily J. Blanchard, Reevaluating the Role of Trade Agreements: Does Investment Globalization Make the WTO Obsolete?, May 2006

1736 Per Engström and Bertil Holmlund, Tax Evasion and Self-Employment in a High-Tax Country: Evidence from Sweden, May 2006

1737 Erkki Koskela and Mikko Puhakka, Cycles and Indeterminacy in Overlapping Generations Economies with Stone-Geary Preferences, May 2006

1738 Saku Aura and Thomas Davidoff, Supply Constraints and Housing Prices, May 2006

1739 Balázs Égert and Ronald MacDonald, Monetary Transmission Mechanism in Transition Economies: Surveying the Surveyable, June 2006

1740 Ben J. Heijdra and Ward E. Romp, Ageing and Growth in the Small Open Economy, June 2006

1741 Robert Fenge and Volker Meier, Subsidies for Wages and Infrastructure: How to Restrain Undesired Immigration, June 2006

1742 Robert S. Chirinko and Debdulal Mallick, The Elasticity of Derived Demand, Factor Substitution and Product Demand: Corrections to Hicks' Formula and Marshall's Four Rules, June 2006

1743 Harry P. Bowen, Haris Munandar and Jean-Marie Viaene, Evidence and Implications of Zipf’s Law for Integrated Economies, June 2006

1744 Markku Lanne and Helmut Luetkepohl, Identifying Monetary Policy Shocks via Changes in Volatility, June 2006

1745 Timo Trimborn, Karl-Josef Koch and Thomas M. Steger, Multi-Dimensional Transitional Dynamics: A Simple Numberical Procedure, June 2006

1746 Vivek H. Dehejia and Yiagadeesen Samy, Labor Standards and Economic Integration in the European Union: An Empirical Analysis, June 2006

1747 Carlo Altavilla and Paul De Grauwe, Forecasting and Combining Competing Models of Exchange Rate Determination, June 2006

1748 Olaf Posch and Klaus Waelde, Natural Volatility, Welfare and Taxation, June 2006

1749 Christian Holzner, Volker Meier and Martin Werding, Workfare, Monitoring, and Efficiency Wages, June 2006 
1750 Steven Brakman, Harry Garretsen and Charles van Marrewijk, Agglomeration and Aid, June 2006

1751 Robert Fenge and Jakob von Weizsäcker, Mixing Bismarck and Child Pension Systems: An Optimum Taxation Approach, June 2006

1752 Helge Berger and Michael Neugart, Labor Courts, Nomination Bias, and Unemployment in Germany, June 2006

1753 Chris van Klaveren, Bernard van Praag and Henriette Maassen van den Brink, A Collective Household Model of Time Allocation - a Comparison of Native Dutch and Immigrant Households in the Netherlands, June 2006

1754 Marko Koethenbuerger, Ex-Post Redistribution in a Federation: Implications for Corrective Policy, July 2006

1755 Axel Dreher, Jan-Egbert Sturm and Heinrich Ursprung, The Impact of Globalization on the Composition of Government Expenditures: Evidence from Panel Data, July 2006

1756 Richard Schmidtke, Private Provision of a Complementary Public Good, July 2006

1757 J. Atsu Amegashie, Intentions and Social Interactions, July 2006

1758 Alessandro Balestrino, Tax Avoidance, Endogenous Social Norms, and the Comparison Income Effect, July 2006

1759 Øystein Thøgersen, Intergenerational Risk Sharing by Means of Pay-as-you-go Programs - an Investigation of Alternative Mechanisms, July 2006

1760 Pascalis Raimondos-Møller and Alan D. Woodland, Steepest Ascent Tariff Reforms, July 2006

1761 Ronald MacDonald and Cezary Wojcik, Catching-up, Inflation Differentials and Credit Booms in a Heterogeneous Monetary Union: Some Implications for EMU and new EU Member States, July 2006

1762 Robert Dur, Status-Seeking in Criminal Subcultures and the Double Dividend of ZeroTolerance, July 2006

1763 Christa Hainz, Business Groups in Emerging Markets - Financial Control and Sequential Investment, July 2006

1764 Didier Laussel and Raymond Riezman, Fixed Transport Costs and International Trade, July 2006 